\title{
OPENINGSREDE VAN ZIJNE EXCELLENTIE BARTHOLOMEUS WOUTER THEODORUS VAN SLOBBE, GOUVERNEUR VAN CURAÇAO, BIJ DE OPENING DER VERGADERING VAN DEN KOLONIALEN RAAD VOOR HET ZITTINGSJAAR 1933-1934
}

\author{
Mijnheer de Voorzitter en Heeren Leden van den Kolonialen Raad.
}

Wederom sta ik in deze zaal, om, ingevolge artikel 77 van het Regeeringsreglement van Curaçao, de vergadering van den Kolonialen Raad voor het nieuwe zittingsjaar te openen.

De Heer Eduard S. Lansberg heeft eenige maanden geleden ontslag genomen als Voorzitter en als lid van Uw college. De Regeering heeft hem dank betuigd voor de diensten, die hij Curaçao heeft bewezen. Ook ik bracht den Heer Lansberg daarvoor gaarne hulde.

Het behaagde Hare Majesteit U, Mijnheer Jossy C. Henriquez, tot Voorzitter te benoemen en $U$, mijnheer de Ondervoorzitter, in dit ambt te handhaven.

Ik wensch U geluk met dit door de Hooge Regeering gegeven blijk van vertrouwen en waardeering.

Ook de Heeren R. S. de Lannoy, Mr. G. H. Eskes en J. H. Sprockel, die werden herbenoemd, en de nieuwe leden D. Capriles en S. A. L. Maduro wensch ik geluk.

Den Heer J. M. L. Maduro, die wegens langdurig verblijf buiten Curaçao ontslag nam als lid van den Raad, dank ik voor de door hem bewezen diensten.

$\mathrm{U}$ allen, Mijne Heeren, dank ik thans persoonlijk voor het vele werk door $U$ in het afgeloopen jaar verricht.

De verhouding tusschen Curaçao en de naburige landen bleef onveranderd gunstig.

De orde en rust onder de bevolking bleven bewaard. De ontevredenheid, die in vele landen heerscht, had weinig vat op de rustige bevolking van dit gebiedsdeel.

Wel worden op het eiland Curaçao invloeden van buiten merkbaar, hetgeen in onze internationale haven met de hier wonende personen van velerlei nationaliteit niet kon uitblijven, doch verwacht mag worden, dat de bevolking zal inzien, met welke oogmerken deze ondergrondsche actie plaats heeft.

Bij de feesten ter herdenking van Willem van Oranje bleek wederom duidelijk, dat de bevolking warme gevoelens ten aanzien van Nederland en het Oranjehuis bezit.

Het is zeer moeilijk aan te geven, in welk stadium de depressie, die 


\section{REDE DOOR DEN GOUVERNEUR VAN CURAÇAO}

over de geheele wereld haar invloed doet gevoelen, thans verkeert.

De toestand is in vele landen zeer zorglijk, ofschoon men zich op velerlei manieren krachtig inspant om de malaise te overwinnen.

Verschillende omstandigheden, waaronder politieke eene voorname plaats innemen, zijn niet gunstig voor eene snelle verbetering.

Laten wij hopen, dat de kleine lichtpunten, die hier en daar zichtbaar zijn, mogen blijken het begin te zijn van het opklaren van den toestand.

De economische toestand van Curaçao is, vergeleken met die van andere landen, niet slecht. De inzinking ging tot nu niet zoo diep, als, in verband met den algemeenen wereldtoestand, kon worden verwacht.

De scheepvaart nam niet verder af; zij vertoonde nu en dan eenezij het ook geringe - opleving, ook wat de vrachten betreft.

De handel verkeert in moeilijkheden. Hij bevindt zich in een overgangstijd en moet zich aanpassen bij de zich wijzigende omstandigheden, hetgeen niet zonder schokken plaats heeft. Gelukkig was het touristenverkeer goed te noemen.

De oogst was over het algemeen voldoende.

Daar de industriëele ondernemingen hare werkzaamheden gedurende het afgeloopen jaar eerder uitbreidden dan in krompen, nam de werkloosheid niet toe.

De directies der groote maatschappijen bevorderen zooveel mogelijk de te werkstelling van bewoners van Curaçao. Er zijn echter werkloozen, die niet willen inzien, dat de tijd van grooten voorspoed voorbij is en dat de bevolking hard moet aanpakken om een behoorlijk bestaan te hebben.

Bijna overal elders is de toestand der werknemers slecht. Hier is nog voor velen, die willen, werk te vinden. Men mag echter niet verwachten, dat de omstandigheden zoo gunstig zullen zijn als eenige jaren geleden, toen een ieder werk kon vinden in het vak, dat hij het zijne noemt.

Ook de industrie maakt zware tijden door; zij moet haar hoofd boven water houden. Het is voor Curaçao van zeer veel belang, dat de industrie hier kan werken onder niet te drukkende voorwaarden.

De toestand van Aruba is niet slecht.

De raffinaderij op San Nicolas werkt op volle kracht. De oogst op Aruba was vrij goed.

Mede doordat het Bestuur, finantieel geholpen door het Nederlandsche Antillenfonds, Bonaire is te hulp gekomen, is de toestand van dit eiland minder zorgwekkend dan verleden jaar.

Saba en - in mindere mate - St. Eustatius werden door een orkaan getroffen. Zeer snel is hulp verleend, waarbij wederom het Nederlandsche Antillenfonds, daartoe in staat gesteld door het Curaçaosche Ondersteuningsfonds, krachtig medewerkte.

De Bovenwindsche eilanden kunnen zich onder de ongunstige tijdsomstandigheden op peil houden. Het Bestuur geeft zooveel mogelijk leiding bij de opheffing dezer eilanden. Eenig resultaat is reeds merkbaar.

Simpsonsbaai, dat jarenlang onder de hoekwormziekte leed, is deze bijna geheel te bovèn gekomen. De bestrijding wordt krachtig voortgezet.

Geruimen tijd scheen het, dat in 1932 de ontvangsten verre bij de 
raming zouden achterblijven. Op het laatst van het jaar bleken de inkomsten ver de verwachtingen te overtreffen. Een aanzienlijk deel der kasvoorschotten kon worden terugbetaald, mede doordat een deel der kasgelden voor dat doel werd bestemd.

In 1932 werden de markthallen afgebouwd en kwam het abattoir tot stand.

De voedselvoorziening van Curaçao geschiedt nu op meer hygienische wijze.

In den loop der laatste jaren is aan de volksgezondheid toenemende aandacht besteed, zooals o.a. blijkt uit de verbetering van het drinkwater, ook in de buitendistricten, uit de saneering en reiniging, uit de bestrijding van in meer of minder mate voorkomende ziekten en uit de zorg voor moeder en kind.

De volksgezondheid is echter nog niet op de hoogte van den tijd.

De bestrijding van de tuberculose is, zooals $U$ bekend is, ter hand genomen. Vermoedelijk zal het Curaçaosche Roode Kruis, dat sinds zijne oprichting reeds veel goed werk heeft gedaan of voorbereid, ook hierbij zijne gewaardeerde hulp verleenen.

De krankzinnigenverpleging eischt reorganisatie.

Indien de middelen blijven vloeien, zooals het zich laat aanzien, zullen in de naaste toekomst weer gelden kunnen worden besteed aan hoogst gewenschte verbeteringen zonder dat de aflossing der kasvoorschotten te veel in het gedrang komt.

Voor de doorvoering van de gelijkstelling van het onderwijs zijn de eerste maatregelen genomen. De ontwerpen ter wijziging van de onderwijsverordening en van de subsidieverordening zijn in het laatste stadium van behandeling. Zoodra Uw college deze heeft voltooid, zullen ontwerpen ter doorvoering van de gelijkstelling worden ingediend.

Het gewone onderwijs mag ongetwijfeld niet worden verwaarloosd, maar rekening moet worden gehouden met het feit, dat eene ver doorgevoerde schoolopleiding een groot aantal personen oplevert, voor wie, in aanmerking genomen hunne ontwikkeling, in het economisch leven geen plaats is.

Vorming van goede ambachtslieden en werklieden is in het belang van het Curaçaosche volk.

Het ambachtsonderwijs heeft daarom de voortdurende aandacht van het Bestuur. De ambachtsschool krijgt spoedig eene aanzienlijke uitbreiding en stelt zich ten doel behalve vaklieden ook geschoolde arbeiders voor de groot-industrie te leveren, opdat de inwoners van Curaçao ook plaatsen, thans nog door niet-Curaçaoënaars bezet, zullen kunnen innemen.

Overwogen wordt de instelling van ambachtsonderwijs op beperkte schaal voor Aruba.

Curaçao mag niet geheel afhankelijk zijn van de groote industrieën.

Andere middelen van bestaan mogen niet worden verwaarloosd.

Eene eenvoudige opleiding voor den tuinbouw en den kleinen landbouw zal worden opgezet.

Bevordering van de visscherij ligt in het plan. Hierbij worden eigenaardige bezwaren ondervonden.

Oprichting van kleine industrieën zou voor Curaçao zeer gewenscht zijn. De tijdsomstandigheden maken deze oprichting zeer moeilijk. De intense productie op elk gebied in landen, waar onder zeer voor- 


\section{REDE DOOR DEN GOUVERNEUR VAN CURAÇAO}

deelige voorwaarden kan worden gewerkt, sluit concurrentie vrijwel uit.

De mogelijkheid bestaat, dat op een of twee der Bovenwindsche eilanden de mijnproductie wordt ter hand genomen.

Ook bestaan er plannen om de goudwinning op Aruba weder op te vatten.

In het afgeloopen jaar kwamen een twintigtal verordeningen tot stand, waarvan de voornaamste zijn:

de regeling der winkelsluiting,

de wijziging van de loodsdienstverordening,

de tijdelijke heffing van een bijzonder invoerrecht op benzine,

de keuring van vee en vleesch en den verkoop van vleesch op $\mathrm{Cu}$ raçao.

het tegen gaan van rookverspreiding,

de wijziging en aanvulling van de pensioenverordening.

Reeds gaf ik aan, dat verordeningen tot regeling van de verdere gelijkstelling van het bijzonder met het openbaar onderwijs in behandeling zijn of binnen kort zullen komen.

Ik ben ervan overtuigd, dat het ontwerp bouwverordening en het ontwerp-havenreglement door $\mathrm{U}$ weldra in behandeling zullen worden genomen.

Ook de wijziging van de filmkeuring vraagt dringend Uw aandacht, daar een beter toezicht op films noodig is.

Hierboven merkte ik op, dat Curaçao economisch niet zoo diep is gezonken als vele andere landen. $\mathrm{Er}$ is echter allerminst reden tot gerustheid. Aan de malaise zal het hoofd moeten worden geboden.

Ik doe een beroep op allen, om vooral nu hunne krachten in te spannen in het belang van Curaçao. Laten wij allen eendrachtig samenwerken, en den moed niet laten zinken. Laten wij, ieder in zijn kring, alles doen, wat de ontwikkeling van het land, dat ons dierbaar is, kan dienen.

Met de bede, dat Gods zegen op onzen arbeid moge rusten verklaar ik de vergadering van den Kolonialen Raad voor het zittingsjaar 1933 -1934 geopend. 